\title{
The African Union and the Destiny of Africahood: The Southern Africa Development Community and Neo- colonial Challenges to Pan-Africanism
}

Godfrey Chikowore

Introductory keynotes

"Only a united Africa can redeem its past glory, renew and reinforce its strength for the realization of its destiny. We are today the richest and yet the poorest of continents, but in unity our continent could smile in a new era of prosperity and power", Kwame Nkrumah, President of the first independent Sub-Saharan African State of Ghana 1957. Abraham Knife, Challenges and prospects of Pan-African Economic Integration. (http//:eiipd.org/publications/occasional\%20papers/ pan_african_eco_integration.htm). 23 October 2003.

"To dominate a people is, above all, to take up arms to destroy, or at least to neutralize, to paralyze, its cultural life. For, with a strong indigenous cultural life, foreign domination cannot be sure of its perpetuation. The value of culture as an element of resistance to foreign domination lies in the fact that culture is the vigorous manifestation on the ideological or idealist plane of the physical and historical reality of the society that is dominated or to be dominated. Culture is simultaneously the fruit of a people's history and a determinant of history, by the positive and negative influence which it exerts on the evolution of relationships between man and his environment, among men or groups of men within a society, as well as among different societies", Amilcar Cabral, the late President of the Republic of Guinnea-Bissau.Centre of Pan African Culture. (http//: hierographics.org/cpacdefined.htm). 14 October 2003. 
"The reality today is that we cannot treat the UN system as given. The institutional arrangements in place were relevant only for a specified period and must inevitably be adapted, transformed or even radically modified as material circumstances have changed and prevailing meanings, practices and purposes have been challenged by new inter-subjective voices,.., what is good for a goose must surely be good for a gander. The present autocracy in global governance must be challenged stoutly so all nations, big or small, have equal say and equal power in the way we govern world affairs", President Robert Gabriel Mugabe of Zimbabwe at the 58th Session of the United Nations General Assembly. (Herald Sept 27, 2003)

\section{Introduction}

With the model of the State in Africa remaining typically an imported one, former colonial powers perceive it their right to extend economic, political and cultural civilization to Africa. Consequently, most former colonies were established in the image of the colonizing master with the constitutional apparatus essentially drawn from the same source. Over time this controversial development has had other consequences which effectively postponed Africahood, meaning the African foundations to all development processes in resonance with the Greater World.

Concentrating much on the political dimension of Africa, the predecessor institution, that is the Organization of the African Unity (OAU) beyond conviction, ensured the political independence of African States but the foundations of the same newly independent states, with regard to African development, were hardly consolidated in social, economic, political, cultural, historical, scientific and technological terms. This essentially means that neo-colonialism is still deeply entrenched in the newly independent African States.

With the evolution of the OAU into the African Union (AU), addressing the economic challenges of Africa-especially after the devastating experiences of economic Structural Adjustment Programs and globalization - the problem of consolidating the pan African foundations of state and nation building on the continent remains equally urgent. Considering the SADC as one of the pivotal 
building blocks of the African Union, and the position it currently occupies against the neo-colonial tendencies, especially 'the land question' in Zimbabwe, it would therefore be morally sound to give a more Afro-centric strategic impetus to the regional cooperation and integration in Southern Africa. Such an approach would mean institutionalization of the problem on consolidating the Pan-African foundations of development on the continent and giving specifically Afro-centric content to the regional development projects and programs, which would finally contributed to the overall Africa development program.

In the light of the above ideological perceptions, therefore, this contribution seeks to:

- explore the opportunities and constraints experienced by African States in the SADC in their efforts to give the pan-African content and meaning to development projects and programs in Southern Africa since the early 1980 s to date;

- critically assess the Pan-African foundations of the economic, political, social, ideological, cultural, historical, scientific and technological choices African governments in the SADC made then and the consequences;

- suggest recommendations on the inevitability of consolidating integrated Pan-African foundations and approaches in development processes in the SADC as a strategy on securing the position and destiny of Africa as a greater competitor both within its limits and in the global setting.

\section{Definition of the topic}

For purposes of guiding this engaging debate in a constructive manner, which would facilitate the broader pursuit of identity, unity and equality in development for Africa and Africans in a global setting, one might usefully proceed from the following considerations:

What is the 'African Union'?: It is the functional physical embodiment of the profound history of African people as a unique race (among other racial groups) and as an integral component of the global community. On a developmental note, the African Union can 
be perceived as an evolutionary institution of the African continent destined to accelerate the process of integration on the continent to enable Africa to play its requisite role in the global economy while addressing multifaceted social, economic and political problems compounded as they are by certain negative aspects of globalization (URL/http.www.Africa-union.org/aboutAU/Abou_in_a_nutshell. htm 21 October 2003).

Equally compelling is the term 'Africahood', which is understood to mean a definitive state of the conscience imbued by African morality, values and integrity typified among other essentials by the air that we breath, our mode of self expression, the words we utter and the blood that flows in our African veins and arteries. It should be noted that Frantz Fanon (1966) and Daniel Tetteh Osabu-Kle (2000) percieve Africahood, as an accention of the cultural heritage of Africa signified by the efforts to uphold an ideology that seeks to emancipate the African from mental slavery resulting from centuries of slavery, colonialism, neocolonialism, and imperialist (now, superpower unilateralist) subjugation. Another very central concept to this debate is 'Pan-African' which refers to a recognition of the need for countries ${ }^{1}$ in Africa to cooperate and help one another. It is the practice of that recognition that we call Pan-Africanism. Another concept that is likely to be confused is 'Pan-African Nationalism',- -which is not synonymous with Pan-Africanism. Pan-African Nationalism is a powerful ideology without which the African or Pan-African cannot be emancipated from mental slavery to rediscover himself or herself. Consequently, Pan-Africanism holds fundamentally that all Africans or Pan-Africans ${ }^{2}$ being all descendants of Mother Africa are equal members of the Jaku family. The anti-thesis of Pan-Africanism, is 'neo-colonialism' ${ }^{3}$ conceived of as the manifestation of an indirect form of control of the former colonies through economic and cultural dependence, and the ruling native elites, compliance with the neo-colonial powers, populations that are exploited for their labour and resources in order to feed an insatiable appetite for finished physical or cultural commodities made by the metropole.

Much more important is the systematic and accurate articulation of these terms within the globalization discourse in as much as PanAfricanism indexes not only a recognition of the need to be supportive 
but also to practice cooperation on which the survival and identity of Africans, and African descendants, has to find expression, as in the SADC development programs. This regional initiative constitutes one of the critical building blocks of the African Union (AU) in the new millennium riddled by complexities of varying magnitude.

\section{Conceptualization of the SADC as an essential Pan-African institution and Africahood}

In a contribution entitled 'Road to Pan-Africanism: another development perspective', dedicated to the occasion of ratification of the SADC protocol on trade, the author accentuated that:

As South Africa prepared for the ratification of the Southern African Development Community (SADC) protocol on trade, there was a need to look beyond trade integration and analyze regional integration....arguing,...the artificial borders that separate the national territories in the SADC region are divisive of people united by history and divisive of regions united by geography to the extent that they are subjects of disputes and conflicts between African states. SADC, he continued...must strive for a community that transcends the economic level and strive for the territorial and political unification of Africa. This is the only way for the continent to become a great modern power. This is the only protection against neo-liberalism and globalization (Pheko 1999:2).

With the signatories of the SADC Treaty (1980) having agreed and adopted the common position that underdevelopment, exploitation, deprivation and backwardness in Southern Africa would only be overcome through economic cooperation and integration, that outcome in itself amounted, as a matter of principle, to the advancement of the cause of Pan-Africanism. Having been the last region in Africa to be under the colonial yoke, but now reaffirming its mission to effect its own route to the Pan-African foundations of development, the SADC adopted economic cooperation as one of the major principal objectives governing the existence of the African Union. Emerging in Southern Africa, this regional bloc further made a positive qualification of Pan-Africanism in the manner that the moral and material support by the African Union (then OAU) 
to the liberation struggles in the SADC signified the continued survival of the African Union. To date, it maintains a functional relevance that accentuates the validity of the political, economic and strategic considerations behind Pan-Africanism. These strategic circumstances are continually reinforced by the prevailing social, economic, political, scientific and technological realities in Africa and internationally, which make co-operation among the sub-Saharan countries even more crucial. Definitely a closer look at the problems, challenges and opportunities of the future by and large strengthens the historically founded gamut of strategic considerations behind PanAfricanism. In the contemporary period such considerations include the menace of HIV/AIDs pandemic, poverty, threat of Great Power unilateralism, general socio-economic stagnation which extensively plague the continent. Certainly, it is in the light of these challenges that the Pan African ${ }^{4}$ essence and Africahood of the SADC as an institution have to find practical expression if the struggle on the restoration of Africa and its mightiness is to become a reality.

\section{Millennium challenges, pan-Africanism and neo-colonial tendencies in the SADC region}

In this age of globalization, one of the main challenges the SADC confronts emanates from the circles of the controversial European Renaissance ${ }^{5}$ which was the foundation of slavery, colonialism, apartheid and racism. These developments have thrown not only Africa but, more precisely, the SADC into a quagmire of underdevelopment, poverty, endless conflicts, economic domination and dictatorship by the Bretton Woods institutions (IMF, WTO, World Bank) as the proponents (of this Pan-European lagery) work hard to perpetuate the holocaust of African people by way of advancing the notion of Pan-Europeanism through the European Union, making themselves a powerful economic bloc, and effectively integrating socially, politically, and working for a borderless Europe across the globe. Actually the advancement of the notion of globalization as a brainchild of ideology of Pan-Europeanism purports to turn the world into a simple global village on European terms, that way dealing another fatal blow to Pan-Africanism. As if Pan-Africanist 
have not yet established that the triumph of Pan-Africanism, the only way Africans could survive the foreign onslaught and live as a truly liberated people, will come out of the sweat and blood of the African people themselves. In the SADC at the moment, the need for a critical Pan-Africanism is quite urgent considering the three schools of thought which have emerged in this Southern African region under the influence of globalization. The first school has seen leaders subscribing to the notion of Pan-Europeanism, that way confirming their full support for the concept of globalization and the neo-liberal as well as neo-colonial circles ${ }^{6}$. With respect to the second school of thought, this could incorporate upholding the Pan-African paradigm comprised of the leadership that is prepared to see the triumph of Pan-Africanism as the only way Africans could survive the foreign onslaught and live as a truly liberated people. Last but not least the third school of thought that has emerged in the SADC in recent times is the one which seeks to accommodate the contemporary progressive elements of both Pan-Africanism and Pan-Europeanism but on the basis of the African Union and the United Nations Conventions or instruments which promote principles of cooperation and integration, sovereignty and equality of states in development. Basically these schools of thought so conspicuously visible in Southern Africa, are indicative of how versatile Pan-Africanism as an ideology vis-à-vis Pan-Europeanism has to be as a means of completely eliminating and minimizing in short, medium and long term the setbacks that have existed in recent times and those that are likely to emerge in the future, having been generated in the Pan-Europeanism legacy (in fact currently globalization is its pivotal weapon) through slavery, colonialism, apartheid and racism. This in reality poses a critical question: other than the traditional ideological sermon adopted as the weapon for advancing the Pan-Africanist cause, what other matching strategy to the Pan-European globalization has been adopted to counterbalance? Could this be seen in the evolutionary process that the economically founded African Union has gone through, from the former politically founded Organization of the African Unity (1963)? If that is so, what then is the qualitative and at most quantitative nature of the evaluation that we give to this process relative to the impact of globalization on the Pan-African mission and cause, not only in Africa but across the globe? 


\section{SADC as a development arm of the African Union}

In the critical research contributions pursued by Njoroge J. Raphael (2002/3) entitled 'AU Integration of African Regional communities into the African Economic Community (AEC) and the African Union' - and by Abraham Kinfe entitled 'The challenges and prospects of Pan-African economic integration' - the conception of the SADC as a development arm of the African Union and, consequently, as a subscriber to the cause of Pan-Africanism was clearly articulated. Within the context of the United Nations sponsored Economic Commission for Africa based in Addis Ababa, Ethiopia and possibly the European Union, the visionary African leaders translated their vision into the creation of regional entities capable of promoting regional cooperation and integration ${ }^{7}$. However, a consolidation of this vision in the form of a principle of development on the basis of Pan-Africanist foundations was expressed in the Lagos Plan of Action for the Economic Development of Africa (1980-2000) in which the vision of the African Union (then OAU) was outlined proposing the establishment of an African Economic Community (AEC) which logically would be preceded by an African Common Market (ACM). With the commitments of the Lagos Plan of Action and the Final Act of Lagos having been translated into concrete terms in Abuja in 1991, the Heads of Government and State concluded the Treaty establishing the African Economic Community (AEC) and it was operationalized from May 1994 onward, with the AEC establishing formal working relations with the regional entities ${ }^{8}$ on the African continent, including the Southern Africa Development Community (SADC) in Southern Africa. Having found definition within the African Union Regional Economic Communities (RECs), specifically in the domain of the African Economic Community (AEC) the SADC, which automatically became an organically indispensable player to the 1991 Abuja Treaty, set modalities for establishing the African Economic Community (EAC). These modalities, which in their advancement of the Pan-Africanist cause the Southern African Development Community (SADC) had to be part of as a strategy for achieving the goal of forming an African Economic Community, constituted five successive stages, namely: 
- $\quad$ Preferential Trade Area (PTA);

- $\quad$ Free Trade Area (FTA);

- $\quad$ Customs Union (CU);

- Common Market (CM) and;

- Economic Community (EC), etc.

With regards to the above mentioned stages viewed as the cornerstone to the consolidation of an African Economic Community, and thereby addressing the Pan-African cause, the SADC is now at the Free Trade Area negotiating stage with a few other remaining member states, Angola, Democratic Republic of the Congo (DRC) and the Seychelles having to accede to the SADC Protocol on Trade?. Under this envisaged Protocol which is catalytic and core to regional cooperation not only in Southern Africa but on the African continent within its system of Regional Economic Communities, substantially all trade will be duty-free by 2008 while the liberalization of countryspecific sensitive products will be accomplished by 2012. However the selective tariff phase down and categorization of SADC member states into the three respective groups of the developed, averagely developed and least developed creates a critical position regarding the combination of the contesting ideological fronts of Pan-Africanism and Pan-Europeanism; each of these fronts in the final analysis will exert influence that promotes the values of its mission but actually at least partially demeans the values of the other contesting ideological front. In the final analysis, what is vital is that the virtues of the overlapping zone of the two have to be promoted on the assumption that they are mutually enhancing on one hand. On the other hand, the vices of the contesting ideologies have to be reduced to the minimum and be effectively eliminated since the assumption at this juncture is that they are mutually retrogressive and time is not on either side, consequently the mutually enhancing dimensions have to be promoted within the set of existing African Union and United Nations (the supra-national institutions) Conventions, in whose framework the SADC as a development arm of the AU is privileged to operate. In Pan-African terms, these provisional categories founded on the principle of asymmetry, should sooner be perceived as a critical unity-reinforcing exposition that should not again be availed to the common historical enemy, the colonialists and the neo- 
colonialists to yet undertake political speculation destined to further divide, rule and plant mutual antagonism ${ }^{10}$ amongst the Africans and most of all the SADC as a united member of the Jaku struggling to consolidate its destiny on Pan-African foundations.

\section{Culturo-ideological challenges of the SADC and Pan-Africanism}

In a contribution entitled, 'Africa, Pan-Africa, Pan-Africanism and Pan-African Nationalism', commenting on the significance of culture and ideology as the basics to Pan-Africanism, the author noted that,

Solutions to African problems can only be found in African culture ${ }^{11}$... for this reason any technology or knowledge should be adapted to African culture in the same manner that the Japanese adapted capitalism to Japanese culture... it emphasizes that the African taken out of culture becomes a commodity or a chattel reminiscent of the era of captive slavery (Osabu-Kle 2000: 3).

In another equally enlightening contribution entitled 'Africa's Peace Fiasco: From 1960 to 1995 ', accentuating the criticality of culture and ideology for state formation especially in Africa in the PostIndependence Era, the author noted that,

We in Africa should inevitably realize that we misconceived the significance of attainment of independence. Furthermore we must be guilty of having underestimated the tasks and efforts which would be required for building a new post-independence state, society and economy..independence was ignorantly assumed to a setting of a golden era and conferring upon Africa a new status at home and abroad.. this assumption was accompanied by the notion that the drafting and execution of four or five year national development plans was the correct vehicle to deliver economic growth, social development and prosperity to the post-independence society (Kambudzi 1998: ix-xii).

In the case of the SADC and the challenges of consolidating the pan-African foundations to the historical mission of reclaiming the African identity, much has to be done to establish the cultural and ideological foundations of that noble undertaking. Notably in the 
SADC and across the African continent the Post-Independence Era saw instead the neo-colonial state emerge and this was symbolized by a continued accumulation by foreign companies and non-indigenous people. Thus, the American and United Kingdom commercial business moguls have continued, still continue and will continue if not tamed sooner, to dominate the main stream of economic development in Southern Africa with the majority of the population remaining marginalized. Thus in real experience the colonial and post-colonial state are quite discernable on one hand while truly on the other hand, the post-colonial state is hardly anywhere nearer to be discerned, thus emphasizing the magnitude of the SADC problem in conveying the development processes in Southern Africa on the PanAfrican foundations. As such in a situation like the contemporary SADC where the neo-colonial state is discernable, politics has been noticed to remain a shared enterprise between the indigenous elite, the ruling party or the opposition parties that assumed or sought to assume political power at independence and foreign business or government. As observed in the above cited critique, the presence of neo-colonial states ${ }^{12}$ on the African continent and in the SADC is characterized by political instability, external economic influence, economic marginalization of the majority and insecure ruling elite alliances.

However notwithstanding the setbacks and the pronounced traces of the neo-colonial state in the SADC and the prospects of developing within the framework of the Pan-African cultural and ideological doctrine, it would be vital to mention the adoption of a draft SADC Protocol on Culture, Information and Sport (coordinated by Mozambique) which in the context of the institutional restructuring of the SADC (since March 09.2001) falls under the Directorate of Social and Human Development and Special Programs. At any rate, while adoption of this Protocol is commendable, the issue is how well will the protocol practically translate into the lives of the SADC population and to what extent will this protocol enhance the cultural ${ }^{13}$ and ideological priorities of the African Union as a Pan-African institution? But at most, for this protocol to translate more meaningfully into the lives of the SADC population as an indispensable part of the African Union advancing the cause of Pan-Africanism, it would be quite strategic to incorporate it in the 
curriculum of primary, higher and tertiary education, emphasizing the priorities and values that give the rationale of Pan-Africanism as opposed to other contesting Pan-Europeanism trends of thought.

\section{Economic Structural Adjustment Programs and Africahood in Southern Africa}

Certainly, considering the socio-economic impact of these US initiated structural adjustment programs since the 90s across Africa and in particular in the SADC, it becomes clear that while these could have facilitated the Pan-African cause on consolidating the position of Mother Africa as an equal player in the global economy, they instead sooner impoverished Africa. With the emergence of the Least Developed Countries (LDCs)+ Highly Indebted Poor Countries (HIPC) in the '90s numbering 41, almost 34 of these were African states and 6 of them SADC member states. The Dependency Syndrome was to stay in Africa and in the SADC as well, that way having to compromise one of the basic principles of Pan-Africanism - economic emancipation of Africa on African terms.

Notwithstanding the fact that the SADC had made remarkable progress in implementing its economic cooperation and integration agenda since the SADC Treaty came into force in 1992 by way of adopting twenty Protocols to provide the legal framework for sectoral activities and programs, it maintained fairly low average economic growth rates. For instance, in 2000 the average economic growth rate in the SADC was 3.2 percent compared to the 1999 rate which stood at a minimal 1.8 percent. In fact throughout the mid-1990s the region recorded growth rates above 2.7 percent. But however as was pointed by Kambudzi (1998) in his examination of the neo-colonial states in the Post-Independence Era, this growth rate was mainly predicated on the output of foreign multinational international corporations with the majority of the SADC nationals being literally marginalized from the main stream of economic development. In fact it was because of the inherent deviation from the Pan-Africanist foundations of economic development which saw the swelling of poverty levels to the tune of forty percent of the population (190 million) in Southern Africa even when the average 
annual population growth rate throughout the '90s was lower than the average economic growth rate experienced in the region through the 90 s. This sooner expressed the highly prejudicial inequalities in the distribution of wealth across the region.

As indicated by available data, trade development reflects great disparities on all levels: regional, intraregional, global. On a regional level South Africa throughout the 1990s contributed about 94 percent of the SACU's exports, while accounting for 98 percent of SACU's imports because then South Africa the biggest export market for Botswana, Lesotho, Namibia and Swaziland. But again South Africa is the biggest source of their imports. For the same period SACU accounted for 41 percent of the SADC's world exports trade and 48 percent of the overall SADC imports in 1997. In all intraregional trade in terms of imports throughout the 90 s in the SADC comprised 7.1 percent of the total SADC world imports. In other words, the SADC member states, imports of goods and services amongst themselves amount to the tune of 7.1 percent while they import from the world to the tune of 86.1 percent, that way showing the higher level of dependency of the SADC on the world market. Such an unfavorable trade trend in which the SADC remains heavily dependent threatens the Pan-African foundations of development in this age of globalization on the African continent a whole. On another note again throughout the 90 s, intra SADC trade exports were to the tune of 14.1 percent while the SADC exports to the world market were to the tune of 87.7 percent again denoting the greater dependence of the SADC on the world market than on its own regional market. In Pan-African terms what this precarious economic position in which trade ${ }^{14}$ is highly to the disadvantage of the SADC means is:

- Efforts on economic emancipation not only by SADC but across the African continent have to be revisited as the economies cannot add value to their commodities, manufacturing has remained underdeveloped;

- The SADC and Africa will remain heavily indebted and may find it difficult to shrug off the neocolonial-bug, unless new alternatives are fashioned out as a matter of urgency, etc. 
Notwithstanding the negativity of the impact of Structural Adjustment Programs, the United States of America and the European Union, as well as Japan and the Far East have remained the largest world markets for most of the SADC member states. Also on a regional level Europe has remained the SADC's largest trading partner receiving the greatest share of the SADC exports over the '90s. Much as Africa should have made a significant contribution in trade terms, she only accounts for 0.5 percent of the total SADC imports, of course excluding SACU imports. Equally, Germany, United States of America, United Kingdom, Japan, Italy and France continue to emerge as top countries of origin of most imports into the SADC. In spite of this development over the 1990-1997 period, the orientation of the SADC exports to Asia had fairly high nominal growth. With new developments emerging such as the US-Africa Growth and Opportunity Act (AGOA), the SADC export volumes to the USA are bound to increase, notwithstanding the divisive nature of this instrument in both short, medium and long term.

However in Pan-African terms, these developments constitute a simultaneous occasion of both opportunities and setbacks depending on the strategies the SADC and Africa adopt on a short, medium and long term. Otherwise instead of engaging its counterparts in trade, the SADC could start contemplating FTAs with any of the host trade partners on the basis of well negotiated commonly agreed national and regional social, economic, cultural as well as scientific and technological priorities. If these trade arrangements which the SADC has with Europe and the rest of the world continue to have the disparity-benefits asymmetry to the disadvantage of the SADC and Africa without their manufacturing industries being developed, with no value added to commodities originating in the SADC destined for the world market, then the Pan-African mission will be considerably compromised, which actually should hardly be the case in the contemporary.

Other than the opportunities or setbacks at the disposition of the Pan-African lagery generated by trade operations in the SADC, the high levels of external debt coupled with declining ratios of development aid pose the same unpleasant situation. In this respect, six SADC countries namely Angola, the Democratic Republic of the Congo (DRC), Malawi, Mozambique, Tanzania and Zambia 
have been classified as severely indebted low income countries; on another note Zimbabwe has been classified as a moderately indebted low income country; Lesotho has been classified as a less indebted low income country.

In a higher category is the moderately indebted middle-income country, Mauritius, while Botswana, the Seychelles, South Africa and Swaziland are classified as the less indebted middle-income countries with Namibia not as yet considered under this system in as much as it does not subscribe to the Debtor Reporting System of the World Bank. At the end of 1999 the total external debt of the SADC member States was US 80.3 billion reflecting a fairly marginal decrease of US 4 billion from the 1998 debt level of US 4 billion. In absolute terms what this means is that each of the fourteen member SADC bloc owes the debtor countries nearly US 6 billion with almost each of the 190 million SADC citizens owing the debtors 31.57 US\$. The unprecedented higher levels of SADC debt to the donor community is disturbing in pan African terms, not even withstanding the fact that the debt burden alleviating HIPC Initiative has accommodated three SADC countries, Mozambique, Malawi and Tanzania. However the registered decrease (US 4 billion) in debt owed by the SADC to the donor community is attributable to the strict debt management policies, avoidance of borrowing by Member states and possibly debt forgiveness under the HIPC Initiative, although debt servicing requirements in hard currency have militated efforts by many SADC countries to make adequate investments in the social/infrastructure and productive sectors and to respond effectively to natural disasters which hit the region 2001. Consequently in Pan-African terms the socio-economic circumstances obtaining in the SADC at the moment still require that regional cooperation and economic integration as the basic concept for transformation, be adapted to the changing regional and global political, social, economic, cultural, scientific and technological circumstances, before the intellectually unchallengeable PanAfrican doctrine loses its meaning in the SADC region and on the wider African continent. 


\section{Political development trends in the SADC within the greater world and pan-Africanism}

The signing of the SADC Protocol on Politics, Defence and Security Cooperation opened up a new and a more strategic platform to deal competently in a predictable manner with the political challenges of the SADC. Such an outcome in the debate raised by Nyamnjoh Francis (2003) in his contribution 'Globalisation, Boundaries, and Livelihoods: Perspectives on Africa', vividly reflects the extent to which Africans in their own right are attempting to Africanize globalization instead of letting Africa be completely globalized. Within the framework of the United Nations Charter reaffirming the UN Security Council in the maintenance of international peace and security, and the role of the Central Organ of the African Union Mechanism for Conflict Prevention, Management and Resolution, the SADC Protocol on Peace, Defence and Security Cooperation put up (among others) its primary objective namely:

- To protect the people and safeguard the development of the region against instability arising from the breakdown of law and order, intra-state conflict, interstate conflict and aggression;

- To develop the peacekeeping capacity of the national defence forces and coordinate the participation of state parties in international and regional peacekeeping operations;

- Consider enforcement action in accordance with international law and as a matter of last resort where peaceful means have failed.

Notwithstanding the enforcement of this Protocol, the SADC has experienced unfavorable political developments and episodes since the 1980s, that way throwing into considerable disarray the Pan-African efforts on bringing stability and prosperity to Africa through economic integration and cooperation. The nearly thirty year devastating armed conflict in Angola brought a lot of socioeconomic hardships which saw Angola being categorized in the '90s as one of the SADC severely indebted countries, together with the Democratic Republic of the Congo, Malawi, Mozambique, Tanzania and Zambia. Huge armies of refugees moved to the neighboring countries as Zambia and Namibia during this period which assumed a more predictable Pan-African character, after the death of Jonas 
Savimbi who had been then declared a rebel by the SADC. The merging of UNITA and the MPLA after Savimbi's death has led to the participation of Angola in the regional integration process on a new horizon that way rationally investing resources for overall development of the country and the region in the final analysis.

Equally compromising the Pan-African mission was the Great Lakes Crisis which saw nearly 3 million people dying and also huge armies of refugees migrating within and beyond the Great Lakes region. While the SADC Allied Forces (Namibia, Zimbabwe, Angola and also Chad) made great positive contributions towards the restoration of peace in the region, neocolonial forces made frantic efforts to decampaign that operation, in spite of the AU, UN and SADC Charter(s) having provisions accommodating the performance of that role by the SADC Forces. Again in this enterprise financial and material resources that could have been rationally invested in the advancement of the Pan-African cause were misused, repelling African invading forces working at the hands of the neo-colonial lagery through its clandestine malicious maneuvers. In the research and academic circles the Great Lakes Crisis has also spoken to the larger political questions that have confronted Africa with a greater intensity than ever before and these center around citizenship and citizenship rights; the state and the governance of the public arena; and the organization of socio-economic development, placing the inevitable demand to design workable frames for addressing these problems as a means of establishing stable democratic systems for the development of the SADC and Africa in the final analysis (Olukoshi 2003).

The other dimension which appears to have compromised the PanAfrican cause was what we could more accurately term "Political Capitalization on Pan-Africanist by Neocolonials/Mechanisation of Pan-Africanist". Instead of turning these Pan-African-Nationalists into potential candidates as ex-offio national ambassadors, or candidates of the Good Offices, the newly emerging African governments would start "for purposes of securing funds with the Bretton Woods Institutions", criminal lawsuits against these highly esteemed personalities even when there was no acceptable rationale to do so. The case in point is lately that of Chiluba`s Era as the former Zambian President in which the Zambian National Constitution was 
even altered to outlaw the veteran nationalist leader Dr Kenneth Kaunda who led Zambia to its independence. At that very time the Zambian Government was selling away all the national wealth to the Multi-National Corporations further impoverishing the nationals. But certainly in the Pan - Africanist lagery, it still remains unclear what virtues the incarceration of Dr Kenneth Kaunda were for the nation but developments sooner indicated that Chiluba's move was gross and disrespectful of the commonly shared African vision. Interventions by the late veteran nationalist the President Mwalimu Juliuos Nyerere of Tanzania, with appeals for the release of Dr Kenneth Kaunda were again not heeded, but otherwise the veteran nationalist found his jail terms relaxed to be under the ethically embarrassing house arrest. Essentially these practices on the part of the young generation of Heads of States and Governments in the SADC and in Africa would sooner generate unnecessary tension amongst citizens that would potentially divert not only resources, but again time and energy of the nationals and worse still give more leverage to the neocolonial forces to frustrate efforts on the fulfillment of the Pan-African mission. Such grossly undesirable experiences in Africa especially when being purposely committed by a head of state and government can have a very devastating effect for national development not only within its context but within the regional and international context as well, especially how it facilitates brain drain to other destinations. In a classical analysis of Pan-Africanism and intellectuals, an accurate observation capping the above undesirable developments that have and still continue to haunt Africa and the SADC region too, stated that,

It was among other such undesirable experiences that while African independence witnessed a flowering of both intellectual activity and Pan African euphoria on the continent, there were also casualties of the post colonial decay which sadly were the intellectual vibrancy and Pan African fervor; the decline was compounded by brain drain from Africa and by the falling standards at major institutions of higher learning and research on the continent; eloquent voices of dissent either went silent or found their way to more receptive lands (Mazrui 2003: 20).

Consequently, while there is need to operate within a global setting the political dimension of the Pan-African mission has to be adapted 
to the changing circumstances essentially within the framework of the respective SADC, AU and finally UN Conventions.

\section{Social development trends in the SADC and Pan-Africanism}

Developments of a social nature occurring in the SADC at the moment are best defined within the framework of the Social and Human Development and Special Programs Directorate. However the most serious challenges have always been related to poverty with over 60 million people or 30 percent of the population of the region living below the internationally recognized poverty datum line of US\$1 per day. This unbecoming development is corroborated by highly depressed social indicators as high levels of malnutrition, illiteracy, unemployment, underemployment, declining levels of life expectancy and very limited access to basic services and infrastructure needed to sustain basic human capacities.

Other very pronounced social problems which have raised obstacles to the fulfilment of the Pan-African cause are refugee flows and the HIV/AIDs pandemic. The conflicts in Angola and the Democratic Republic of the Congo have led to massive displacement of the population internally with that of Angola working to the tune of $2 \mathrm{mln}$. In 1998 out of a total of 702,000 refugees in the SADC, Tanzania was home to about 300,000 refugees, the Democratic Republic of the Congo was home to 200,000 while Zambia was home to 160,000 refugees. Such massive flows have had and continue to have negative effects on the economy with a greater part of the uprooted population having no access to the means of production and literally putting pressure on the environment, natural resources and government services. The World Bank emerged with a rough estimate of the costs of refugees to the host country in Africa to the tune of US\$530 mln per year. With the same figure invested for production or improvement of the infrastructure, this would have a positive impact on the welfare not only of SADC but the African continent as a whole.

Last but not least is the problem of HIV/AIDs pandemic which threatens also the Pan-African cause for peace and development in 
the region. Currently, there is an estimated total of 4 million AIDs cases and about 10 million cases living with positive HIV/AIDs that way accounting for nearly 5 percent of the total population in the region. This is a very devastating situation if one considers in labor market terms the magnitude of per capita labor loss in both production and skills. The SADC has adopted a Strategic Framework and Program of Action on HIV/AIDS for 2000-2004 with a goal to reduce the number of HIV/AIDS infected and affected individuals and families in the region. This will ensure that HIV/AIDS will no longer be a threat to the public. At the same time the SADC has always advocated for access to affordable drugs and has forthwith established the Bulk Purchasing Technical Committee with also the demand for compulsory licensing, parallel importation and local manufacturing of pharmaceuticals being considered as mechanisms for facilitating access to more affordable drugs. Again within the Pan-African paradigm this is a challenge that has to be resolved together with other key players to ensure a gradual elimination of the health threat caused by HIV/AIDS to the public in the SADC and on the African continent as a whole.

\section{SADC and its scientific and technological disposition}

One of the major setbacks to the efforts on making robust national economies in the SADC is the absence of consistent science and technology programs although Africa Technology and Policy Studies (ATPS) and its respective National Chapters across the SADC is making considerable inroads in advancing the cause for coming up with a policy that would be promotive of the requisite technologies for the varied specific countries and their priorities within the SADC and in Africa as a whole. Again notwithstanding the fact that manufactured value added is so low in the SADC economies, the most appropriate directorate, that is trade, industry, finance and investment where actually science and technology should have been identified as a special sector on its own is nowhere to be seen, that way scuttling the hopes scientific and technological development founded in an understanding of African priorities and interests. This actually raises critical questions as to how urgent and whether this science and technology ${ }^{15}$ is really conceived as a priority in 
the development of the SADC economies as they contribute to the fulfillment of the Pan-African cause. This is one of the other major reasons which explains why most of the exports from the SADC have no value added to them (see 3.3). Centers of specialization in science and technology have to be established, with funds mobilized, and develop the entreprenueral as well as the innovative capacities of the nationals in an effort to improve the productive base of the manufacturing sector of all SADC economies.

\section{Operative solutions and recommendations to the challenge of consolidating Pan-African foundations to approaches on eradicating neo-colonial tendencies in the SADC region}

In the contemporary world, the Pan-African mission has equally weighing opportunities and constraints emanating from the nature of underlying principles in the political economy of development initially between the developed and developing world as well as between particular African countries and particular developed countries (in the contemporary the USA and Britain versus Zimbabwe). In their combination the Pan-African has to exploit the existing opportunities and work out commensurate strategies which will give a milage to the effort on fulfilling the Pan-African cause.

\section{The Great Powers cooperation}

As of now the World Powers especially the USA and Britain together with Members of the European Union have to respect the spirit and conscience guiding the SADC Treaty in deeds and words. This fundamental principle was highly emphasized by President Robert Mugabe of Zimbabwe at the 58th UN General Assembly in New York when he criticized the unfortunate emergence of the powerful nations such as Britain and the USA which sought to dominate the world and dictate to other countries how they should govern themselves (Herald Sept 27.2003). Take the example of Africa Growth and Opportunities Act 2000 (AGOA) which while it purports to revive 
economic growth through trade promotion on the African continent still selectively limits that provision to only thirty five countries notwithstanding the fact that Africa has fifty three states which are all in great need of funding and revival of industrialization processes in the contemporary. At best AGOA should have been adopted as an all Africa embracing corrective instrument to redress the devastating setbacks which the US initiated: ESAPs inflicted on the African and the SADC economies over the 1990s period. Moreover again its main area of focus, that is apparel which may in most cases not be the priority area for development in the SADC or the African Union seeking equally economic transformation, sooner indicates the existence of other motives behind AGOA than what the initiative is exactly purported to serve. Far from it, the African Union and the SADC guided by the Pan-African philosophy cannot fully realize the goal of Pan-Africanism through trade in apparel which in the long run will mean again the domestic markets of these countries having sooner to be flooded by apparel goods from the USA (read footnote 14). Otherwise left as it is the World Powers, especially the USA and Britain, will just be imposing themselves on the weaker SADC, African Union that way eroding the values and priorities of the latter while promoting the western neo-colonial values and priorities unfortunately, in the Pan-African lagery.

\section{Alternative operational solutions}

\section{Global perspective}

On a global perspective the position of the SADC as arm of the African Union advancing the Pan- African cause has to be recognized in the Bretton Woods institutions in the manner of the latter being receptive to the social, economic, political, cultural, scientific and technological priorities and interests of the SADC. This would facilitate the implementation of programs and enhance the sense of ownership amongst the African population in the SADC. The inequalities in trade and generally socio-economic development would be even much narrower getting finally eradicated if the global institutions were receptive in principle and in practice towards the development efforts by the SADC. Failure of the Pan-African cause 
on this perspective has to be brought up as question to the IMF, World Bank and the World Trade Organization, that in spite of humanitarian essence of the philosophy that drive them, why is it that the world and especially Africa and the SADC have been riddled with poverty and diseases with no end in sight even then?

\section{Continental perspective}

On the level of the continent the African Union Charter has been more definitive in the Peace and Security issues with now a super continental army having to ensure peace on the continent, without having to wait for the UN peacekeeping forces which of late have been visibly selective and in most cases not receptive to the demand for peace on the African continent. The most recent example was the limited number of forces sent to the DRC and even then only to Bunia (only an urban settlement) under the leadership of the European Union. In real combative terms this contingent has not scored any success that could add much to the Pan-African cause. At any rate the SADC Allied Forces (Zimbabwe, Namibia, Angola and Chad) did much in combative terms than what the present EU led UN military mission to the DRC has done in the small tribal rivalry stricken northern city of Bunia where it is taking pains to bring sanity. So again with all due fairness and respect for the sovereignty and the right to freedom and equality of African states and the SADC members, the outer world has to be receptive to the mission of the $\mathrm{AU}$ and its sub-regional bodies, otherwise conflicts will remain endless on the continent, that way spending resources which would have otherwise been appropriately invested more productively.

\section{Regional perspective}

On the regional perspective in the upholding of the Pan-African cause there has to be a united SADC front and the emergence of a Peace and Security Council in Southern Africa is strategic. This would then mean that any threats to peace so essential for faster development will be dealt with immediately without again having to wait for the United Nations Forces whose receptiveness has become 
very controversial in the contemporary mostly due to the expansion of unilateral tendencies in the camp of the Great Powers led by the errant USA and the United Kingdom. A supportive stand of the SADC members as a community has a more positive implication for the Pan-African cause than if these countries were to otherwise adopt a unilateralistic approach. Here the case in point is the support which the SADC community continues to give Zimbabwe over its implementation of the land resettlement program (greatly opposed by the self imposing United Kingdom and the USA) on the principle of equity and equality across racial groups against the racially biased former colonially instituted land tenure system whereby each(of the 4500 farmers of British descent) white farmer had 2-3-5 and even 15 farms on one hand while the majority of the blacks were mostly crowded in rural areas with agriculturally non-viable soils on the other hand.

\section{National perspective}

On a national level African values have to be upheld and the African child taught and reminded through media, education and arts about the dangers of adopting alien cultures and the magnificence, greatness of upholding your own culture, sticking to the doctrine of Africahood. The SADC has to be promotive at national levels of the practices that add value to the Pan-African cause and equally intolerant of practices be they economic, political, social, cultural, psychological, scientific and technological which tend to militate accomplishment of the Pan-African cause in essence.

\section{Conclusion}

Certainly in this new millennium when the world is rapidly changing, the Pan-African cause remains the only guiding philosophy to the salvation of Africans and at the disposal of the African Union, the SADC and other sub-regional formations charged with the mission to contribute to the reconstruction of Africa not on neocolonial but essentially Pan-African foundations. As should always be the case unity of purpose among African States and adherence 
to the principles of the founding Charters of the SADC, African Union, United Nations in the battle for consolidating Pan-African foundations for development and transformation in the SADC and the African continent as a whole should remain as the unshakable guiding beacon.

\section{Explanatory endnotes}

1. Means the extended boundaries of Africa that is, the whole of Africa and not just the continent of Africa with Madagascar because the historical forces of slavery, neo-colonialism and immigration extended the boundaries of Africa into Europe, the Americas and Asia (all people of African descent are Africans including the Macaronis of the Indian sub continent, and the Nigritos of Papua New Guinea and the Philippines whose very African features suggest that they migrated from Africa at some point in their history). As such those interested in studies concerning the whole of Africa- pan Africa are called Pan Africanists and may or may not be necessarily Africans. On another note academics interested in studies limited to the continent of Africa with Madagascar are contented with calling themselves Africanists and may not be Africans again as such, Dr. Daniel Tetteh Osabu-Kle, 2000, Africa, Pan-Africa, Pan Africanism and Pan African Nationalism.(http//: www.expotimes.net/issue000816/osabu.htm, independent, Sierra Leone, 16-29 August,2000). 14 October 2003.

2. Irrespective of their particular locations on this planet, they belong to one and one only true nation- the African Nation- to which the great civilizations of Egypt, Nubia, Axum, Ethiopia, Ghana, Mali, Songhai and Zimbabwe also belong. What matters is Mother Africa or the Jaku- their common African family, ibid p2 of 4.

3. According to Kwame Nkrumah (1965) neo-colonialism is ... the worst form of imperialism. For those who practice neocolonialism, it means power without responsibility and for those who suffer from it, it means exploitation without redress... among other things neocolonialism continues to actively control the affairs of the newly independent states, Leong Yew, Research 
Fellow, University Scholars Programme, National University of Singapore: Neocolonialism- Political Discourse - Theories of Colonialism and Post Colonialism: (http.www.scholars.nus.edu. $\mathrm{sg} /$ landow/post/poldiscourse/neocolonialism.html), 21 October 2003.

4. Pan-Africanism demands that the riches of Africa be used for the benefit, upliftment, development and enjoyment of the African people. Pan-Africanism is a system of equitably sharing food, clothing, homes, education, healthcare, wealth, land, work, security of life and happiness. Pan-Africanism is the priviledge of African people to love themselves and to give themselves and their way of life respect and preference, Pfeko, 1999, Road to Pan-Africanism- another development perspective. (http:// library.wustl.edu/ listmgr/devel-1/Nov 1999/0000.html). 23 October 2003. and Abrahim,Kinfe., The challenge and prospects of PanAfrican economic integration.hth://www.eiipd.org/publications/ occassional). 23 October 2003.

5. In August a prominent Nigerian political scientist had to remind the participants of the fifth Pan-African Colloquium in Ghana of the historical context of the European Renaissance from which the so-called African Renaissance was purportedly being made to borrow that way placing it on a high risk of transposing its rationale. Arguing that European Renaissance was the origin and foundation of slavery, colonialism, apartheid and racism, the exponents of this European Renaissance are still advancing their forces in the fashion of Pan-Europeanism while other African leaders were visibly dragging their feet on the implementation of Pan-Africanism and have made Africa a perpetual beggar of foreign aid, ibid, p3 of 4.

6. This situation in fact helps to explain why when there is the urgency of settling issues which pertain to the Pan-Africanist circles some of the African leaders visibly drag their feet having already in ideological terms confirmed that they are agents of neo-liberalism and neo-colonialism whose instrument is globalization. In contesting real ideological terms both the 
Pan-Africanists and Pan-Europeanists do realize that globalization is a new form of the re-colonization of not only the African continent but the whole former colonial world including the former socialist countries which then had not as yet succumbed to the notion of Pan-Europeanism.

7. Peter, J. Schraeder, 2000, African politics and society, (Boston: Loyola University Press), p.307.

8. These are the regional and sub-regional economic blocs meant to promote regional cooperation and economic integration on the African continent chiefly as a strategy on advancing the cause of the Pan-Africanist paradigm which purports to reverse the setbacks to the African conscience and mentality that were generated by slavery, colonialism, apartheid and racism at the hands of the exponents of European renaissance reliving as Pan-Europeanism and now having the form of expression as neo-colonialism and lately through the instrument called globalization. Specifically the referred to AU-AEC regional entities (Regional Economic Communities) are the: Community of Sahel-Saharan States (CENSAD) established Feb.04.1998; Common Market for Eastern and Southern Africa (COMESA) founded in 1993 but succeeded in 1994 the Preferential Trade Area for Eastern and Southern Africa (PTA) established in 1981; Economic Community of the Central African States(ECCAS) established in October.18.1983 by way of uniting the Central African Customs and Economic Union (UDEAC) and the Economic Community of the Great Lakes States (CEPGL); Economic Community of West African States ( ECOWAS) established May.28.1975; Intergovernmental Authority for Development (IGAD) established in March 21.1996 as a successor to the Intergovernmental Authority on Drought and Development (IGADD) established 1986; the SADC established in 1992 as a successor to the SADCC established in 1980; Union du Maghreb Arabe (UMA) established February 17.1989 in Marrakech. About OAU (http://www.africa-union.org/About_ AU/Abrecs.htm]. 21 October 2003. 
9. Launched in September 2000, the SADC Trade Protocol will catalyze the process of regional economic cooperation and integration in Southern Africa. The Trade Negotiating Forum (TNF) as defined in the Protocol negotiates and recommends trade agreements for the Committee of Ministers of Trade and as far as tariffs are concerned, the TNF designed a tariff phase down (on the basis of the principle of asymmetry) so as to accommodate the different levels of economic development in the region. Consequently in the first category there are Southern African Customs Union (SACU) member states comprising Botswana, Lesotho, Namibia, South Africa and Swaziland; in the second category there is Zimbabwe and Mauritius; while in the third and least category there is Malawi, Mozambique, Tanzania and Zambia. In the light of this tariff phase down schedule, the relatively developed SACU countries would front load its tariff phase down, while Zimbabwe and Mauritius would mid-load, and the remaining from the least developed category would tariff phase down having to be back loaded. The front, mid and back loading applies to goods in category B and C while goods in category A are for immediate liberalization, Source: The Official SADC Trade, Industry and Investment Review., 2002, Southern African Marketing Co (Pty)Ltd, Gaborone, p22-23.

10.The cases in point are the intra-regional conflicts generated through the mechanizations of the neo-colonial forces originating in Pan-European circles which have seen the Great Lakes crisis exercerbating poverty in already poverty stricken regions that are actually notable as humanitarian crisis regions in the United Nations record. Since 1998 a death toll of nearly 2.5 million has been registered coupled by a huge army of refugees within the conflict zone and migrating to neighboring African countries in spite of all the efforts the SADC, the AU and UN (with marked reservation indeed) are making to reconcile these conflicting beligerants. The devastating sixteen year war experienced in Mozambique, and the highly impoverishing twenty-seven year war experienced in Angola are regrettably living testimonies or experiences of the critical challenges that the Pan-African struggle has to face up to and chart its way forward. 
11.Because of their emphasis on African culture, the Pan-African Nationalists of today are often described as Afro-Centric. In equally the same manner that the Japanese use their Emperor as their ideological axis and call upon all Japanese to revere the Emperor and rid themselves of the Barbarians, Pan-African nationalists use Mother Africa as the ideological axis and call upon all Africans to revere Mother Africa and rid themselves of the barbarian excrescence of mental slavery. This reverence of Mother Africa has been an inseparable part of the African psyche from time immemorial and it explains why Africans pray to God by pouring libation to Mother Africa (the Jaku) symbolized as the ground, ibid Daniel Tetteh Osabu-Kle 2000.

12.Making an insight into the neo-colonial phenomenon, Kambudzi AM, accentuates the fact that, "the truth is unavoidable-that is independence came, but with the formal inheritance of a state as well as a false nation which obscured real nations.. what were nations to become were fatally dubbed "tribes," both before and after independence. Kambudzi, A.M., 1998, Africa`s peace fiasco: from 1960 to 1995 , UZ publications, Harare, p xii.

13.As a matter of factually acknowledging the significance of culture and ideology for regional integration in Southern Africa the SADC Treaty of 1980 defines one of its objectives as "the strengthening and consolidation of the long standing historical, social and cultural affinities and links among the peoples of the region". And in order to achieve this objective, the SADC would among the series of strategies to its disposal "mobilize the peoples of the region and their institutions to take initiatives to develop economic, social and cultural ties across the region, and to participate fully in the implementation of the programs and operations of SADC and its institutions, The SADC Official Trade, Industry and Investment Review.,2002, Southern African Marketing Co (Pty) Ltd + SADC, Gaberone, pp 14-15.

14.By the Pan-African yardstick trade trends in the SADC throughout the 1990s to date reflect more of risks than opportunities because the trade ratio of intra-SADC, and that of the SADC and the 
World was [1:6.2] for imports; and [1:7.1] for exports, thus reflecting highly distorted trade imbalance against the SADC: Source- Official SADC trade, industry and investment review, 2002, Southern African Marketing Co (Pty) Ltd, Gaborone, p42. Again while the Africa Growth and Opportunities Act could have development advantages for Africa, its selective application makes it more of a political weapon to rule and divide Africa and even its sub-regions of which the SADC is an integral part. This USA trade initiative for sub-Saharan Africa became effective in October 2000. Under this instrument, all SADC countries are legible with the exception of Angola, Democratic Republic of the Congo and Zimbabwe. Across Africa thirty five countries have been eligible of which 29 are regarded as Lesser Developed Beneficiary Countries which qualify for an additional preference of duty free and quota free market access for apparel originating anywhere in the world until 30 Sept 2004 after which date they would require to meet a different set of rules of origin that will require cloth to be imported from either the USA or from AGOA eligible countries. Under AGOA except for Botswana, Mauritius, Namibia, Seychelles and South Africa all the rest are categorized as Lesser Developed. In order to qualify for exporting garments under AGOA eligible countries have to establish an effective Visa System with strong enforcement mechanisms and verification procedures in place to ensure compliance with the rules of origin. By June 2001 three SADC countries Mauritius, Lesotho and South Africa had qualified for the Visa system while Malawi, Swaziland, Botswana, Mozambique, Namibia, Tanzania and Zambia were under consideration. It is quite a controversial arrangement in terms of its essence and what the Pan-African mission is meant to achieve. Moreover it is not negotiated within the African Union development platform for it to get well synchronized, therefore it comes in as an alien effort which is not driven by the African conscience and spirit.

15.An existing program identified as "Program on Industrial Research and Development" has been initiated with the aim to strengthen the region's capability in industrial development, and to enable its effective contribution to the socio-economic 
development of the region, through establishing a process of sustainable industrialization in the SADC. Ibid, $p$ 48. However this program is not getting the exact momentum as indicated by continually depressed levels of manufacturing and fairly high levels of raw materials constituting the exports of the SADC to the outer world.

\section{Bibliography}

Abdel, A.J., ed., 2003, The challenges of globalization to democratic governance in Africa: What role for civil society and other stakeholders?, Addis Ababa, Zebu Printers Cooperative.

Adedeji, Adebayo., ed., 1993, Africa within the world, London: Zed for ACDESS.

Alioune, S., ed., 2000, 'The future competitiveness of African Economies', Proceedings of the Dakar Forum, March 1999, Dakar, African Features, Karthala, Sankore. African Union in a nutshell, (http://www.Africaunion.org/About AU/Abau in a nutshell.htm), 21 October 2003.

African Union- An Mbendi profile, (http://www.mbendi.co.za/oroau.htm), 14 October 2003.

About AU-Regional Economic Communities (RECs), (http://www.africaunion.org/About AU/Abrecs.htm, 21 October 2003.

Basic facts about the United Nations, 1995, New York, UN Publications.

Chumbow, B.S., 2003, 'The language question and national development in Africa', Paper presented at the CODESRIA 30 Anniversary 1973-2003 Grand Finale, 10-12 December, Dakar, Senegal.

Culture as resistance, Amilcar Cabral, the late President of the Republic of Guinea-Bissau, Centre of Pan African Culture. (URL:http:// hierographics.org/cpacdefined.htm). 14 October 2003.

Herald Zimbabwe, 2003, September 27.

Kambudzi, A.M., 1998, Africa`s Peace Fiasco: From 1960 to 1995, University of Zimbabwe Publications, Harare.Knife, Abraham., The challenges and prospects of Pan-African Economic Integration. URL; http://www.eiipd.org/publications/accassional\%20papers/pan african eco integration.htm.p15) 23 October 2003.

IIiffe, John.,1995, Africans: The history of a continent, Cambridge University Press, Cambridge. 
Leong, Yew., Neo colonialism. Political discourse- Theories of Colonialism and Post colonialism. (URL:http://www.scholars.nus.edu.sg/landow/ post/poldiscourse/neocolonialism1.html). 21 October 2003.

Mazrui, A.A., 2001, Pan-Africanism and the globalization of Africa: A triple process, Second Lecture, DuBois Centre, Ghana, November. Revised November 2001. (URL:http://igcs.binhamton.edu/igcs site/ dirton13.htm.p10). 14 October 2003.

Mazrui, A.A., 2003, 'Pan Africanism and the intellectuals: rise, decline and revival', Paper presented at the CODESRIA $30^{\text {th }}$ Anniversary Grand Finale, Dakar, Senegal.

Mama, A., 2003, 'Gender studies for Africa's Transformation', Paper presented at the CODESRIA $30^{\text {th }}$ Anniversary Grand Finale, 10-13 December, Dakar, Senegal.

Moyo, S., 1998, 'Land entitlement and growing poverty in Southern Africa', Southern African Political and Economic Monthly, vol. 11,No.5.

Mkandawire, T., 2003, 'African intellectuals and nationalism', Paper presented at the CODESRIA $30^{\text {th }}$ Anniversary Grand Finale, 10-12 December, Dakar, Senegal.

National Model AU 2004, Constitutive Act of the African Union, National Model African Union Conference.(http://www.moau-au.org constitutive act of the African union-html). 14 October 2003.

Nyamnjoh, F.B., 2003, 'Globalisation, Boundaries and Livelihoods: Perspectives on Africa', Philosophia Africana, Vol. 6 No. 2.

Nkrumah, Kwame,1965, Neo-Colonialism: The last stage of imperialism, London, Thomas Nelson and Sons.

Olukoshi, A., 2003, 'CODESRIA: 30 years of Social Research, Knowledge Production and Pan African Networking: Synopsis of the report of the Executive Secretary'. Paper presented at the CODESRIA $30^{\text {th }}$ Anniversary Grand Finale, 10-12 December, Dakar, Senegal.

Official SADC Trade, Industry and Investment Review., 2002, Southern Africa Marketing Co (Pty) Ltd in Association with the SADC, Gaborone.

Osabu-Kle, Daniel. Tetteh., 2000, Africa, Pan Africa, Pan Africanism and Pan African Nationalism, Expo Times Exposing today for tomorrow, Independent, Sierra Leone,16-29 August 2000. (http://www.expotimes. het/issue000816/osabu.htm). 14 October 2003.

Pheko, Motsoko,1999, Road to Pan-Africanism - another development perspective, Johannesburg, the Sowetan, November 15, 1999. (URL: http://library.wustl.edu/ listmgr/devel-1/Nov1999/0000.html). 23 
October 2003.

Raphael, J. Njoroge, Integration of African Regional Communities into the African Economic Community (AEC) and The African Union (AU), Research Associate- Worcester Polytechnic Institute.

Rodney, Walter, 1972, How Europe Underdeveloped Africa, London: Bogle-L` Ouverture Publications.

Sachikonye, Lloyd., 1989, 'Debate on democracy in contemporary Zimbabwe', Review of African Political Economy, No 45/56, pp. 117125.

Schraeder, Peter J., 2000, African politics and society, Boston: Loyola University Press.

SADC Protocol on Politics, Defence and Security Co-operation. 